\title{
HELMINTH ENDOPARASITES OF BLACK DRONGO, DICRURUS MACROCERCUS (PASSERIFORMES: DICRURIDAE) FROM CHATTOGRAM, BANGLADESH
}

\author{
Rajib Acharjee* and Toufikul Islam \\ Department of Zoology, University of Chittagong, \\ Chittagong-4331, Bangladesh
}

\begin{abstract}
The common passerine bird species of Bangladesh, the Black Drongo (Dicrurus macrocercus), was collected between November 2013 and March 2014 from paddy fields around the Chittagong University campus to study endohelminth parasites. In total, four helminth adult parasite species, one trematoda (Eumegacetes triangularis), one cestoda (Notopentorchis sp.), two nematoda (Viguiera dicrurusi and Diplotriaena bargusinica) and single unidentified pleurocercoid larva were evident from the body cavity and digestive tracts of the sampled birds. With prevalence, mean intensity and abundance of 52.94\%, $3.33 \pm$ 3.04 and 1.76, respectively. It was apparent that the nematodes were the most prevalent (41.18\%) species and the male $(60 \%)$ hosts were found to be more susceptible to infection with the helminths. The mean intensity and the abundance of male also followed the same trend. However, the maximum (100\%) prevalence was in February 2014. Parasitic abundance was found to be dependent with total length $(t=40.19, p=0.000)$, body length $(t=31.97, p=0.000)$ and body weight $(\mathrm{t}=39.88, \mathrm{p}=0.000$ ) of the host. Among the identified helminths $E$. triangularis, Notopentorchis sp. and Diplotriaena bargusinica are the new records for Bangladesh and from the present host. Stomach contents showed that the bird is affirmed as insectivorous, predominant abundance of insect (97-100\%) having an abundance gradient of lepidopteran $>$ odonates > dipteran > coleopterans $>$ hemipterans $>$ hymenopterans. The present study coincided with the winter and spring season of an isolated study area, i.e. Chittagong University campus only. Therefore, a detailed study is expected to have a complete helminth profile and epidemiological aspects of the present host at different ecological areas of the country.
\end{abstract}

Key words: Black Drongo, passerine birds, helminths, new records, stomach contents, insectivore, Chittagong University campus.

\section{INTRODUCTION}

Amongst the 36 orders of the world's bird species (del Hoyo 2014), birds from 21 different orders are found in Bangladesh and like the rest of the world the highest number of species of birds in Bangladesh belong to a single order named Passeriformes that includes almost 300 bird species (IUCN Bangladesh 2015). The family Dicruridae belongs to the order Passeriformes. From the evolutionary

*Author for correspondence: <rajibacharjee@cu.ac.bd>

() 2018 Zoological Society of Bangladesh DOI: https://doi.org/10.3329/bjz.v47i1.42054 
history with particular reference to Indian Ocean islands, it was found that all the Dicrurus species of this region are included in the clade $G$ and Dicrurus adsimilis and $D$. macrocercus are sister species with very much distinction from another species D. modestus (Pasquet et al. 2007) though the later one still considered as a subspecies of $D$. adsimilis by others (BirdLife International 2006).

The Black Drongo (D. macrocercus), host of the present study, is a medium sized passerine bird, native to much of southern Asia (Grimmett et al. 1999). In Bangladesh, it occurs mainly in the villages all over the country and feeds upon insects, both the larvae and adults, that are considered crop pests (Chandy 2003; Asokan et al. 2009) and occasionally on amphibians, reptiles, fish, birds and bats (Ali and Ripley 1983; D'Silva et al. 1990; Senthilmurugan 2005). Because of positive role of the Black Drongo on agriculture as biological pest control agent, many researches have studied the ecology and behaviour (Raju and Rao 2004, Senthilmurugan 2005), breeding (Grimmett et al. 1999; Ali et al. 2010), growth and development (Shukkur and Joseph 1978, Nair 1995, Ali et al. 2010), genetics (Pasquet et al. 2007) and economic importance (Asokan et al. 2009). In contrast, only a few works were conducted on the parasites and diseases of this host and the works aimed mainly on the ectoparasites (bird lice) (Uchida 1927), cestodes (Duggal and Gupta 1987) and nematodes (Gupta 1960; Sood and Kalia 1978, Nandi 2005). Surprisingly, no parasitological works has been done on the present host in Bangladesh though Gupta (1960) conducted his work in East Pakistan (present Bangladesh) in the sixties. In addition, the works previously done in other countries of the world except India, ectoparasites, protozoan as well as helminth parasites were recorded from various host species of the family Dicruridae other than the present host (Ishtiaq et al. 2007, Sychra et al. 2011). Therefore, the present study initiated with the goal to identify endo-parasitic helminths of the Black Drongo as host and to evaluate their various infestation parameters.

\section{MATERIAL AND METHODS}

A total of 17 (10 males and 7 females) host Black Drongo samples were collected by shooting at different paddy field sites around the Chittagong University campus between November 2013 and March 2014. The moribund host samples were euthanized following animal handling procedure approved by international guidelines (AVMA 2007).

Each sample was sexed and given an identification code. The mean total length, mean body length and mean body weight of the hosts were taken. Longitudinal incision was made along the length from esophagus to rectum for 
helminth prospection and carefully analyzed using stereo-microscope. The entire digestive tract was removed, and the body cavity washed with physiological saline solution in a petri dish. The collected helminth parasites were fixed with hot AFA (alcohol-formol-acetic) for trematodes and cestodes and GA (glycerinealcohol) for nematode to restrict their morphological deterioration. Half of these fixed parasites were preserved into $70 \%$ alcohol and the rest in lactophenol for clearing and microscopic identification. Microdissection of the parasites were also done wherever needed for detailed taxonomic identification. Microphotographs were taken by digital cameras (Sony DSC-T90, Samsung ES99 and Optika Digital Microscopy, Optika 4083.B5). The scheme of classification and taxonomic features were mainly followed after Yamaguti $(1959,1961,1985 \mathrm{a}$, 1985b, 1985c), with additional consultations from Anderson et al. (2009), Wardle and McLeod (1952), Chandler (1949) and some verified online resources. In addition, stomach contents of the host were analyzed by gravimetric method proposed by Man and Hodgkiss (1977) and $60^{\circ} \mathrm{C}$ temperature was used for evaporating the water to make the wet sample dry. Statistical analyses were done with SPSS (version 16.0).

\section{RESULTS AND DISCUSSION}

Of the examined Black Drongo samples of 10 males and 7 females, 9 (52.94\%) hosts were found to be infected with four species of adult helminth, viz., Eumegacetes triangularis (Trematoda, Or. Digenia; F. Eumegacitidae; infected site: intestine), Notopentorchis sp. (Cestoda, Or. Cyclophyllidea; F. Delipdidae; infected site: intestine), Viguiera dicrurusi (Nematoda, Or. Spiruridea; F. Habronematidae; infected site: stomach) and Diplotriaena bargusinica (Nematoda, Or. Filariidae; F. Diplotriaenidae; infected site: body cavity). In addition, one unidentified pleurocercoid larva was isolated (Fig. 1). Previously, Duggal and Gupta (1986) and Gupta (1960) reported Notopentorchis sp. from the present host at Chandigarh in India, though the species is not the same. Considering the reports on other parasites from Black Drongo in former East Pakistan, three of the identified parasitic species from this study, viz. E. triangularis, Notopentorchis sp. and D. bargusinica are new records for Bangladesh. In addition, the Black Drongo is the new host record for these parasites. However, till now no work except Gupta (1960) was found to be done on the Black Drungo. Most of the works on birds have reported other parasites and thus no comparison could possibly be made for this study.

According to the necropsy result, the overall prevalence, mean intensity and abundance were $52.94 \%, 3.33 \pm 1.01$ and 1.76 , respectively. In addition, the

prevalence rate changed from 5.88 to $41.18 \%$ based on the species of 

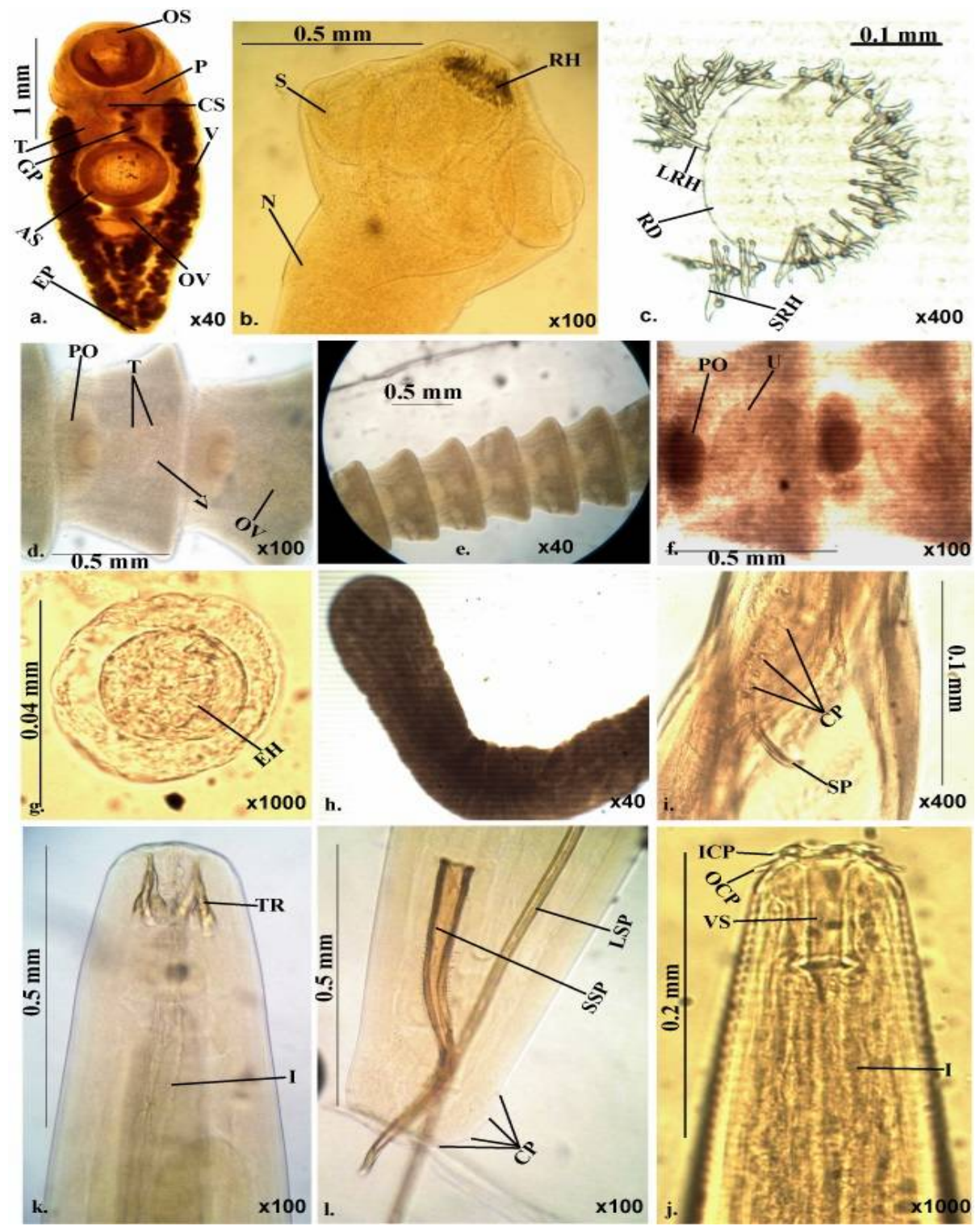

Fig. 1a-1: Microphotographs representing various taxonomic characters of the identified helminth parasite from Black Drongo (Dicrurus macrocercus). a. Eumegacetes triangularis whole body; b. Notopentorchis sp. scolex; c. Notopentorchis sp. rostellar hooks; d. Notopentorchis sp. mature proglottids; e. Notopentorchis sp. alternating genital pore; f. Notopentorchis sp. gravid proglottids; g. Notopentorchis sp. onchosphere; h. unidentified pleurocercoid larva; i. Viguiera dicrurusi anterior end; j. V. dicrurusi posterior end (male); k. Diplotriaena bargusinica anterior end; 1. D. bargusinica posterior end. Abbreviations: AS: Acetabulum sucker; CP: Caudal papillae; CS: Cirrus sac; EH: Embryonic hook; EP: Excretory pore; GP: Genital pore; I: Intestine; ICP: Inner cutting plate; LRH: Large rostellar hook; LSP: Large spicule; N: Neck; OCP: Outer cutting plate; OS: Oral sucker; OV: Ovary; P: Pharynx; PO: Paruterine organ; RD: Rostellar disc; RH: Rostellar hooks; S: Sucker; SP: Spicule; SRH: Smaller rostellar hooks; SSP: Smaller spicule; T: Testes; TR: Trident; U: Uterus; V: Vitellaria; VS: Vestibule. 
helminthes. Nematode parasites were more prevalent parasite species though the cestode had the highest intensity (Table 1). In case of nematodes, $V$. dicrurusi was more abundant parasite. Two cases of mixed infection, in one case $E$. triangularis with $D$. bargusinica and $V$. dicrurusi, and in another case Notopentorchis sp. with $D$. bargusinica and $V$. dicrurusi, were observed during the study though all these parasites differ in their niche preference, viz. $E$. triangularis in large intestine, Notopentorchis sp. in small intestine, $D$. bargusinica in body cavity and $V$. dicrurusi in stomach.

The male was found to be infected $(60 \%, 6$ out of 10) more than the female $(42.86 \%, 3$ out of 7$)$. The prevalence, mean intensity and abundance in male were $60 \%, 2.0 \pm 0.87$ and 2.00 , respectively, while in female were $42.85 \%, 1.42 \pm$ 1.11 and 1.43, respectively. Due to small sample size of the male and female hosts, no statistical test was done to find out relationship within the sex and parasite abundance.

Maximum prevalence (100\%) was observed in February while maximum parasites were recovered in November followed by December and January, and the lowest parasites were in March (Fig. 2). The mean total length, mean body length and mean body weight of the hosts were $46.81 \pm 3.74 \mathrm{~cm}, 1.05 \pm 2.61 \mathrm{~cm}$ and $55.54 \pm 3.99 \mathrm{gm}$, respectively. However, the parasite distribution among the hosts were found to be dependent on the total length $(t=40.19, p=0.000)$, body length $(\mathrm{t}=31.97, \mathrm{p}=0.000)$ and body weight $(\mathrm{t}=39.88, \mathrm{p}=0.000)$ of the host, though from correlation analysis no significant relationship was found between these host parameters and the parasite abundance.

The mean total length, mean body length and mean body weight of male were $48.64 \pm 1.03,32.25 \pm 0.81$ and $55.31 \pm 1.47$, respectively. From t-test analysis, the enumerated values for parasite and body length $(\mathrm{t}=-22.786, \mathrm{p}=$ $0.000)$, parasite and total length $(t=-30.65, p=0.000)$ and parasite and body weight $(t=-28.31, p=0.000)$ showed dependency of parasite distribution with host morphometry, though negative but highly significant. As expected, no significant correlation was found between parasites and any of the host's parameters.

On the other hand, the mean total length, mean body length and mean body weight of female were $44.13 \pm 0.99,29.34 \pm 0.61$ and $55.18 \pm 1.15$, respectively, and negative but highly significant dependency was found between parasite distribution and host total length $(\mathrm{t}=-33.74, \mathrm{p}=0.000)$, body length $(\mathrm{t}=$ $-26.33, p=0.000)$ and body weight $(t=-27.06, p=0.000)$. Correlation analysis could not produce significant relation between the host parameters and parasite distribution. 


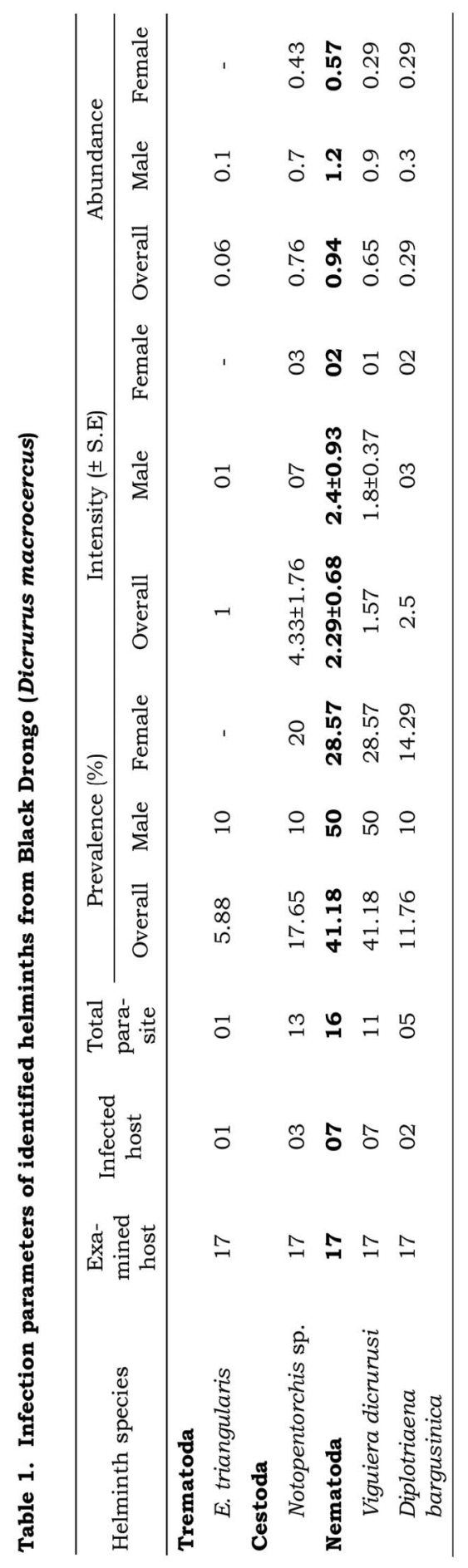


The stomach content analysis showed that the insect body parts was the highest (97-100\%) which included both adults and larvae of insects and only 0$4 \%$ of cases fruits and grains. Among the insects, the observed abundance series was lepidopteran $>$ odonates $>$ dipteran $>$ coleopterans $>$ hemipterans $>$ hymenopterans. From statistical analysis it was found that the parasite abundance was dependent on the animal part of the stomach content $(t=$ $-126.45, p=0.000$ ), but no significant correlation was found from correlation analysis. The fruits and grains in the stomach might have been found as passive accumulation from the ingested animal part since no reports has been found to record about their herbivorous feeding.

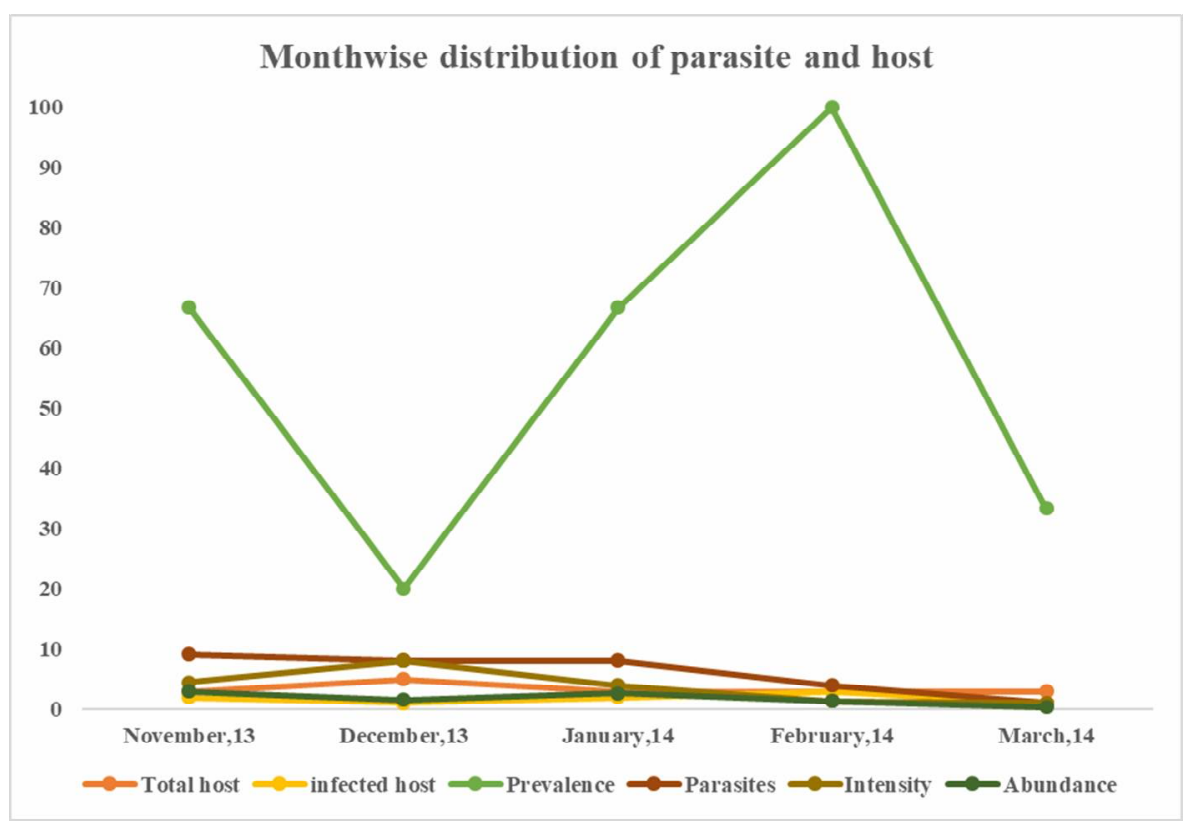

Fig. 2. Monthly distribution of parasites and their infection parameters in Black Drongo (Dicrurus macrocercus).

The overall prevalence rate of helminths reported in the present study seemed to be a bit higher (52.94\%) which could likely be linked with the variation in feeding preferences. The Black Drongo use different habitats, feeding strategies and diversity of prey. These Drongos feed primarily on insects, amphibians, reptiles and birds, thereby, being exposed to a high number of potential intermediate host species (Price 1980), resulting in greater helminth richness which was supported by the present data derived from the stomach content analysis. However, nematodes from 20 families have already been reported to act as insect-parasitic species upon the insect belongs to the orders 
Coleoptera, Diptera, Orthoptera, Lepidoptera and Hymenoptera (Daniel et al. 2008).

The trematodes were rare in the present study, restricted to single infection of Eumegacetes triangularis (Fig. 2). Several digenean such as the species that parasitize birds and amphibians, have been reported parasitizing dragonfly larvae as second intermediate or paratenic host (Stafford 1931, Snyder and Janovy Jr 1994, Kumari and Madhavi 1994) and these helminths have also been recorded as adult parasites in various vertebrate hosts (Travassos et al. 1969). Pinto et al. (2013) for the first time reported metacercariae, identified as Eumegacetes medioxiums, in case of natural infection of larval dragonflies in the Neotropical region. From food analysis of Black Drongo, it was found that the larvae and adults of odonatan constituted a considerable portion in their food items. Therefore, it can be concluded that the occurrence of this parasite in this host might not be accidental rather than natural selection and the present host is the definitive host for this parasite species. However, previously this parasite was recorded from Passer domesticus, Glareola planticola, and many other host bird species (Yamaguti 1985a).

Like the trematode cestode species, Notopentorchis sp. was found to infect the Black Drongo (Fig. 1b-g). All the species of this genus found in swifts from the Old World (Georgiev and Bray 1991) though N. kherai was recorded from the present host by Duggal and Sushma (1986) in India. Of the known nine species of this genus, three species $N$. bovieni; $N$. cyathiformis and $N$. vesiculata belong to a group with rostellar hooks of clearly distinct length in each of the two rostellar rows (Dimitrova et al. 2017, Mariaux and Georgiev 2018) and the remaining 6 were not found to be completely similar with the present species, though $N$. collocaliae had most similarity with the present species but differ in three aspects (i) total number of the rostellar hooks (30-35 in N. collocaliae but 40-41 in present species) (Fig. 1b-c), (ii) length of the rostellar hooks in both rostellar rows; and (iii) host preference ( $N$. collocaliae from a swift host from Sri Lanka while the present species from Black Drongo). However, previously Duggal and Sushma (1986) reported $N$. kherai from the present host but unfortunately the description they provided suited mostly with the genera Biuterina and Sphaeruterina rather than the present genus and so considered as species incertae sedis along with another species $N$. hindia (also reported from India but very briefly described and without figure) (Georgiev and Bray 1991). Due to poor condition of the samples, genital structure could not be studied completely in the present study so no conclusion about the species could possibly be made. Based on earlier explanation, however, it can be concluded that the present cestode is the new record from this host and also from 
Bangladesh. The highest prevalence as well as the highest number of parasites was recovered for this parasite (Table 1). Among the two nematode species, $V$. dicrurusi, a spirurid nematode was recovered from the stomach. This parasite showed the highest prevalence and maximum number of the parasites was also belong to this nematode species (Table 1). Like other helminth species of this study, no previous report was found to compare with the present study. However, among 20 species of this genus, 9 have been described from the Indian subcontinent (Nandi 2005). Morphologically the worms in this study agree mainly with the description of Viguiera viduae, but metrically come closer with the V. dicrurusi (Fig. 1i-j). Gupta (1960) described V. dicrurusi from Dicrurus macrocercus albirictus in East Pakistan (Bangladesh) and Chabaud (1960) described $V$. viduae from Dicrurus forficatus in Madagascar and also distinguished $V$. dicrurusi from $V$. viduae by the longer left spicule and smaller eggs, though, in actual, there were no substantial morphological differences amongst $V$. dicrurusi and V. viduae (Nandi 2005). Three other species of Viguiera have been descried from India from similar or related host species to that of $V$. dicrurusi, namely $V$. bhujangai from $D$. adsimilis macrocercus; $V$. adsimilisai from $D$. adsimilis; and $V$. majumdari from $D$. macrocercus macrocercus (Nandi 2005). However, the cephalic structure and number of caudal papillae (10 pairs) of $V$. majumdari clearly distinguish it from V. dicrurusi. Gupta (1960) considered V. euryoptera reported by Singh (1949) from India was a wrong identification and may belong to $V$. dicrurusi. All three forms are close to $V$. dicrurusi in metrical data and general morphology.

The other nematode species was Diplotriaena bargusinica is a filarial worm and was collected from body cavity of the host (Fig. 1k-1), though all the recorded species of this genus has been reported from thoracic and abdominal air sacs of various species of Passeriformes (Anderson 1992, Macwhirter 1994), Psittaformes, Anseriformes and Faliconiformes (Keymer 1982). However, some earlier reports stated that they were also found in body cavities (Gupta and Johri 1988, Sathyanarayana and Tamilarasu 1989), but these are thought to be erroneous and may well have been due to postmortem migration (Anderson 1992). The distribution of these worms is reported to be worldwide (Borji and Razmyar 2011). However, a critical review on molecular identification along with very distinct morphometric characters is mandatory to validate the species of Diplotriaena because most of the recorded 26 species from South Asia might be the synonyms (Sood 2006). However, D. bargusinica reported from Indian Myna (Acridotheres tristis tristis) in India, Cryirina formosae himalayensis in Nepal (Soota and Chaturvedi 1967, Soota and Chaturvedi 1972). Therefore, the present host is the new host record for this parasite from Bangladesh. Recently, 
Vieira et al. (2017) conducted morphological, molecular and phylogenetic analyses of $D$. bargusinica. The life cycle of the worm involves insects ingesting the worm eggs which contains an infective third-stage larva, which then emerges and undergoes complex migration through the small intestine, liver, posterior vena cava, heart, pulmonary arteries, lungs and finally the thoracic and abdominal air sacs (Young et al. 1998). As the present host is an insectivorous host so the occurrence of this parasite in the present host was specific rather than accidental. Macwhirter (1994) reported low prevalence in most species of birds affected with the species under this genus. In the present study, the prevalence was also low (11.76\%) and the female hosts had higher prevalence than the male (Table 1). Hamerton (as reported by Keymer 1982) stated that Diplotriaena was pathogenic in birds with pneumonia and lung consolidation. Other studies reported 'fits' and sudden death in birds due to microfilariae plugging the cerebral capillaries (Keymer 1982). Bockheim and Congdon (2001) stated that nematodiasis, including Diplotriaena species infection, can cause central nervous system disturbance, diarrhea, marked weight loss and loss of appetite.

\section{CONCLUSION}

Susceptibility of the Black Drongo to helminth infection might be attributed by the dominant insectivorous feeding habit and involvement of the insects as intermediate or paratenic host for a number of birds' helminth species, including the trematodes, cestodes and nematodes, has already been established. Previous studies proved that Diplotriaena species has pathogenicity to their host despite of having lower prevalence rate, though in the present study all the host samples were found asymptomatic not only for Diplotriaena, but also for other identified helminth species, which was confirmed just the reflection of the predatory effectiveness as well as the internal physiological homeostasis after incision. The present study coincided with the winter and spring season of Chittagong University campus only. Therefore, a full-scale study is needed to have a complete helminth profile and epidemiological aspects of the present host under different ecological areas year round of the country.

Acknowledgements: The authors would like to appreciate the scholastic suggestions of Professor Benazir Ahmed and Professor Md. Abdul Gofur Khan of the Department of Zoology, University of Chittagong, for their guidance and crosschecking of the parasites. The authors would also like to thank all who supported the sample collection and laboratory works. 


\section{LITERATURE CITED}

Ali, A.M.S., Asokan, S., Manikannan, R. and Nithiyanandam G.T. 2010. Nest-site characteristics and breeding biology of the Black Drongo Dicrurus macrocercus in Cauvery Delta, Southern India. World Applied Sciences Journal. 9(11): 1280-1285.

Ali, S. and Ripley, S.D.1983. Handbook of the birds of India and Pakistan. Compact edition. Delhi: Oxford University Press.

Anderson, R.C. 1992. Nematode parasites of vertebrates, their development and transmission. CAB International: Wallingford, U.K.

Asokan, S., Ali, A.M.S., Manikannan, R. 2009. Diet of three insectivorous birds in Nagapattinam District, Tamil Nadu. India - a preliminary study. Journal of Threatened Taxa.1(6):327-330.

AVMA. 2007. American Veterinary Medical Association. Guidelines on Euthanasia. Available from http://www.avma.org/issue/anima\_welfare/euthanasia.pdf.

BirdLife International, 2006. Species fact sheet: Dicrurus adsmilis. Downloaded from http://www.birdlife.org.on.

Bockheim, G., and Congdon, S. 2001. The Sturnidae husbandry manual and resources guide. Disney Animal Kingdom. Lake Buena Vista, U.S.A.

Borji, H. and Razmyar, J. 2011. Detection of Diplotriaena spp. from the body cavity of Myna (Acridotheres tristis) in Mashhad, Iran. Sci. Parasitol. 12(4): 223-225.

Chabaud, A.G. 1960. Quatre Spirurides parasites d'oiseaux malgaches (1). Mem. Inst. Sci. Madagascar, Ser. A, 14:105-124.

Chandler, A.C. 1949. Introduction to Parasitology. New York. Wiley.

Chandy, M. 2003. Ph.D thesis. Kottayam, India: Mahatma Gandhi University.

Daniel, L.M., Whitaker, P. and Ridgway, N. 2008. Biological Control of Insects and Mites: An Introduction to Beneficial Natural Enemies and Their Use in Pest Management. University of Wisconsin, Madison, WI53706.

D'Silva, C., Sankaran, R., Mohapatra, K.K. and Chandra, J. 1990. Indian Black Drongo Dicrurus adsimilis eating a bird. J Bombay Nat His Soc. 87(2): 301.

del Hoyo, J., Elliot, A. and Christie, D.A.(eds) 2014. Handbook of the Birds of the World. Vol. 11. Old World Flycatchers to Old Wworld Warblers. Lynx Edicions: Barcelona.

Dimitrova, Y., Mariaux, J. and Georgiev, B. 2017. Redescriptions of four Palaeotropical species of the cestode genus Notopentorchis Burt, 1938 (Cyclophyllidea: Paruterinidae). Zootaxa 4290: 61-82.

Duggal, C.L. and Sushma, G. 1986. On Notopentorchis kherai, a new Asian cestode (Dilepididae) parasitizing Dicrurus macrocercus at Chandigarh, India. Acta Parasitologica Polonica. 31(1-2):15.

Duggal, C.L. and Gupta, S., 1987. On a new avian cestode, Paruterina dicruri, from Black drongo, Dicrurus macrocercus at Chandigarh, India. Rivista di Parasitologia 48(1): 89-92.

Georgiev, B.B. and Bray, R.A. 1991. Notopentorchis cyathiformis (Frolich, 1791) n. comb. and $N$. iduncula (Spasskii, 1946) (Cestode: Paruterinidae) from Palaearctic swifts (Aves: Apodiformes), with a review of the genus Notopentorchis Burt, 1938. Systematic Parasitology 20: 121-133.

Grimmett, R., Inskipp, C., Inskipp, T. 1999. A guide to the birds of India, Pakistan, Nepal, Bangladesh, Bhutan, Sri Lanka, and Maldives. Princeton, New Jersey, USA: Princeton University Press, 888.

Gupta, S.P. 1960. Nematode parasites of vertebrates of East Pakistan V. Spirurid nematodes. Can. J. Zool. 38: 575-584.

Gupta, V., and Johri, S. 1988. On some filarid nematode parasites of birds from Lucknow. Indian. J. Helminthol. 40:109-120. 
Ishtiaq, F., Gering, E., Rappole, J.H., Rahmani, A.R., Jhala, Y.V., Dove, C.J., Milensky, C., Olson, S.L., Peirce M.A. and Fleischer R.C. 2007. Prevalence and diversity of avian hematozoan parasites in Aisa: A regional survey. Journal of Wildlife Diseases. 43(3): 382-398.

IUCN Bangladesh.2015. Red List of Bangladesh Volume 3: Birds. IUCN, International Union for Conservation of Nature, Bangladesh Country Office, Dhaka, Bangladesh, xvi+676.

Keymer, I.F. 1982. Parasitic diseases, Diseases of cage and aviary birds. $2^{\text {nd }}$ ed. Lea Febiger: Philadelphia.

Kumari, V.G.M.S. and Madhavi, R. 1994. The life cycle of Eumegacetes artamii Mehra, 1935 (Trematoda, Eumegacetidae). Acta Parasitol. 39(1): 9-12.

Macwhirter, P. 1994. Passeriformes: diseases, Avian medicine: principles and application. Wingers publishing: Florida.

Man, H.S.H. and Hodgkiss, I.J. 1977. Studies on the ichtyo-fauna in Plover Cove Reservoir, Hong Kong: feeding and food relations, J. Fish Biol.11:1-13.

Mariaux, J. and Georgiev, B.B. 2018. Seven new species of cestode parasites (Neodermata, Platyhelminthes) from Australian birds. European Journal of Taxonomy. 440:1-42.

Nandi, A.P. 2005. Data on the morphology of Viguiera dicrurusi Gupta, 1960 (Nematoda: Habronematidae) with notes on related forms. Folia Parasitologica. 52: 261-266.

Pasquest, E., Jean-Mar, P., Fuchs J., Cruaud C., Bretagnolle, V. 2007. Evolutionary history and biogeography of the drongos (Dicruridae), a tropical Old World clade of corvoid passerines. Molecular Phylogenetics and Evolution 45(2007): 158- 167.

Pinto, H.A. and Melo, A.L. 2013. Metacercariae of Eumegacetes medioximus (Digenea: Eumegacetidae) in larvae of Odonata from Brazil. Biota Neotrop. 13(2): 351-354.

Price, P.W. 1980. Evolutionary biology of parasites. Princeton University Press, Princeton, NJ, p.3.

Raju, A.J.S. and Rao, S.P. 2004. Passerine bird pollination and fruiting behaviour in a dry season blooming tree species, Erythrina suberosa Roxb. (Fabaceae) in the Eastern Ghats forests, India. Ornithological Science 3(2): 139-144.

Sathyanarayana, M.C. and Tamilarasu, P. 1989. Helminth parasites of selected birds of Mayiladuthurai area, Tamil Nadu. Indian J. Helminthol. 24: 22-25.

Senthilmurugan, B. 2005. Fish in the diet of the Black Drongo. J. Bombay Nat. Hist. Soc. 102(1):116

Shukkur, E.A.A., and Joseph, K.J. 1980. Proximity nesting of the Black Drongo and the Redvented Bulbul In Proceedings of the All India Symposium of Environmental Biology. Department of Zoology, University of Kerala, 40-42.

Singh, S.N. 1949. Sur le Spiroptere des pies-grieches. Bull. Soc. Hist. Nat. Afr. Nord. 5: 223-225.

Snyder, S.D. and Janovy Jr, J. 1994. Second intermediate host-specificity of Haematoloechus complexus and Haematoloechus medioplexus (Digenea: Haematoloechidae). J. Parasitol. 80(6): 1052-1055.

Sood, M.L. 2006. Nematode parasites of birds (including poultry) from South Asia. International Book Distribution Co., Lucknow (India)

Sood, M.L. and Kalia, R. 1978. Viguiera adsimilisai n. sp. (Nematoda: Spiruridae) from Dicrurus adsimilis from Indian. Riv. Parasitol. 39: 23-25.

Soota T.D. Chaturvedi Y.1967. On two new species of nematode from the intestine of the snowcock, Tetraogallus himalayensis Gray. Journal of the Zoological Society of India 19(1/2): 133-136.

Soota T.D. and Chaturvedi, Y. 1972. Systematic studies on some ore nematodes from the unarmed collections of the zoological survey of India. Rec. Zool. Surv. India. 67:121-137.

Stafford, E.W.1931. Platyhelmia in aquatic Insects and Crustacea. J. Parasitol. 18:131. 
Sychra, O., Palma, R.L., Saxena, A.K., Ahmed, A., Bansal, N., and Adam, C. 2011. Chewing lice of the genus Phillopterus (Phthiraptera: Philopteridae) from drongos (Passeriformes: Dicruridae). Zootaxa. 2868: 51-61.

Travassos, L., Frezitas, J.F.T. and Kohn, A. 1969. Trematodeos do Brasil. Mem. Inst. Oswaldo Cruz. 67: $1-886$.

Uchida, S. 1927. Studies on amblycerous Mallophaga of Japan. Journal of the College of Agriculture, Tokyo. 9(1):1-56.

Vieira, T.D., de Macedo, M.R.P., and Bernardon, F. 2017. Morphological, molecular and phylogenetic analyses of Diplotriaena bargusinica Skrjabin, 1917 (Nematoda: Diplotriaenidae). Parasitology International. 66(2017): 555-559.

Wardle, R.A. and McLeod, J.A. 1952. The zoology of tapeworm. University of Minnesota Press. 780

Yamaguti, S. 1959. Systema Helminthus. Vol II. The Cestodes of Vertebrates. Interscience Publishers, New York, 860.

Yamaguti, S. 1961. Systema Helminthum. Vol. III. The Nematodes of vertebrates. Part I and II. Interscience Publishers, New York, London. 1261.

Yamaguti, S. 1985a. Systema Helminthum. Vol. I. The digenetic trematodes of vertebrates. Part I and II. International Books and periodicals Supply Service, Indian reprint, New Delhi. 1575.

Yamaguti, S. 1985b. Systema Helminthum. Vol. II. The Cestodes of vertebrates. International Books and periodicals Supply Service, Indian reprint, New Delhi. 860.

Yamaguti, S. 1985c. Systema Helminthum. Vol. III. The Nematodes of vertebrates. Part I and II. International Books and periodicals Supply Service, Indian reprint, New Delhi.

Young, E.A., Cornish, T.E. and Little, S.E. 1998. Concomitant mycotic and verminous pneumonia in a blue jay from Georgia. J. Wildlife Dis. 34(3): 625-628. 